\title{
The ruling classes and the experience of fear
}

\author{
Alberto Abruzzese \\ Emeritus Professor of Sociology of Cultural and Communication Processes, University Institute for \\ Modern Languages (IULM) of Milan, Italy
}

The inner crisis in the governmental capabilities of today's leaderships reveals their reputational failings, despite social imaginaries being even more split between historical institutions and daily life. In order to interpret the increasing clash between financial capitalism's economic-political dynamics and democratic values (ethical, aesthetic and political), it does not suffice to have a cultural and professional training linked to the modes of writing, which is the medium that reflects humanity's and modern individuals' historic background. It requires stopping the progressivist thought of civilization as well as its practices and its regimes of sense.

Keywords: leadership, reputation, writing, humanism, fear, sacrality, power hungriness

Neither, however, everything we read in the holy scriptures was in fact written before the advent of the Lord, if not to announce his advent and to prefigure the Church to come, that is to say the people of God through all the nations that is his body. ... [T] he things that have been written before, have been written for our instruction and have been a representation of ours ... (St Augustin, De Catechizandis Rudibus, III, 6; IV, 7)

When we read, someone else is thinking for us: we merely repeat his mental process. It is like when the student learns to write with the pen going over the pencil marks of the master. So when one reads, most of the thought-activity has been removed from him. Hence the palpable relief we perceive when we stop to take care of our own thoughts and move on to reading. While we read, our head is truly an arena of unknown thoughts. But if we take away these thoughts, what's left? So it happens that those who read a lot and for most of the day, in the meantime relaxing with a carefree pastime, little by little lose the ability to think - like one who always rides a horse and eventually forgets how to walk. This is the case of many scholars: they have read to the point of becoming fools. (Schopenhauer 1851 [1974])

The image is perhaps the only remaining link with the sacred: with the fright caused by death and sacrifice, with the serenity that comes from the covenant between those who are sacrificed and those who sacrifice them, and with the joy of representation which is inseparable from sacrifice, its only possible ford. ... Between the alertness of judgment and the immersion into the cells, with the black presence of pleasure, there exists a transition that I would compare to thought: not to the reasoning-calculation that combines, argues and decides, but to irruption of the sensible into the signs, to the etching of the signs into the sensible. ... Isn't this precisely that passage of thought into suffering and eroticism, which was sensed in every age, beyond the domain of religions, as essence of the sacred? (Kristeva 2011) 


\section{INTRODUCTION}

The national and international background of the themes covered in this paper is the deep crisis of governance capability of the ruling classes (in terms of content and media) and the decline of their reputation in the face of a collective imagination that the media has developed in forms ever more divorced from the reality of social relations, and from the knowledge and practices of historical institutions. Against this background - now marked by the epochal clash between the economic and political dynamics of financial capitalism and the ethical, aesthetic, and political values of democracy - we address some crucial points in the terminal crisis of the models of intellectual and professional growth and maturation that are still bound to writing, a medium and metaphor for the world, based on the totalizing and anthropocentric contents of Humanism.

The conceptual leap we need to grasp in order to break the deadlock of the educational agencies, both public and private, can only consist in a radical shift from the prescriptive sphere of social ethics to the experiential sphere of the individual. This is a goal that can only be achieved by breaking the religious and social traditions that education continues to transmit, even though they have been exposed by now as emptied of all meaning: so much so that they are the main cause of the failure of the leadership, its ineptitude and inanity, if not its blatantly dishonest and criminal life.

Finally, we speculate as to what the individual can resort to that is just as powerful as a religious spirit (both traditional and secular). And this can only be the realm of the sacred: the primordial place in which the human condition is shown first as fear of the world, then as struggle for survival, and finally as the will to power. The representation of this not-yet-civilized humanity, forced to recognize its irredeemable longing for violence and pain, devoid of all original or future hope and salvation, requires a complete erasure of the progressive thought of civilization, or at the very least a separation from its practices. It requires an inner resistance to the dominant values of organized communities, to their regimes of sense.

\section{THE DOUBLE TRUTH}

The three epigraphs shown at the beginning of this paper provide a line of reasoning: since the intellectual and professional education of the ruling classes is still linked to writing as a medium and as a metaphor, ${ }^{1}$ the epochal leap to seize, so as to break its religious and social traditions, consists in deciding what can be found just as intense and powerful, which will allow each of us to immerse in it our own thought. ${ }^{2}$ What, if not the secret sphere, deprived of language, of the sacred? Of suffering and sensual pleasures? And therefore of the person: the place where the human condition is shown as fear of self and of the other, the need to survive, and then the will to power, violence. This is a place with neither grace nor hope. ${ }^{3}$ By simplifying and

1. See Abruzzese (1996); Bolter and Grusin (1999); De Kerckhove (2008); Eisenstein (1979); Frasca (2005); Harris (1986); Havelock (1963; 1986); Illich (1993); Innis (1950; 1951); Landow (1992); McLuhan (1962); Moretti (1996); Ong (1982).

2. On the ambiguity of 'us', see Abruzzese (2011).

3. For the definition of person we refer - with some divergence, however - to the fundamental contribution of Roberto Esposito (2012); for the analogy between the idea of grace and the secular idea, see Bloch (1959). 
schematizing. ${ }^{4}$ We want to argue here that, in the historic transition from traditional media to personal-digital media, the historical contents of education are definitely inadequate to obtain in practice any actual social innovation (assuming, but not taking for granted, as we will discuss later, that this really is the leap forward that humanity needs). Even in the face of an increasingly technological world that is changing ever more rapidly, for decades the educational and academic institutions - the set of agencies that govern schools and universities - have tried to adapt to the complexity of contemporary systems by resorting to all sorts of gimmicks and to low-grade opportunism. These actions, however, have invariably conformed to the methods of political reformism: to re-form, that is to give new shape to the same old content. To reform, in order to restore and preserve. A theory of the historical monument and a protocol of immutable cultural heritage. Protected by law. So conceived, reformism cuts across several different powers and several different ideologies. The result of democratization processes triggered by market dynamics on a global scale, it concerns the ambivalence of human nature - torn between desire and fear of the unexpected - and of institutions whose controlling officers draw sustenance for their own survival from the habitudinary substance of inhabiting, from its emotional limits, its fears. The vision that spurs reformism consists in the exercise of a double truth.$^{5}$ On the one hand, this is expressed in a substantially negative assessment and conceptualization of technology, and specifically of the technological media. This is even more true now that, from all directions, they saturate human life and every form of its material and immaterial

4. To apologize for a process of simplification and schematization is a custom, when - as in this paper - there is a lack of space to articulate and cite the academic discourse in its fullness. Incidentally, however, it seems to me that, compared to other 'academic' approaches and so, as in my case, compared to sociology (discourse on society, on vertical and centralized forms of territoriality) - mediology (discourse on communication, reworked starting from the post-industrial media, that is to say from horizontal and decentralized forms of territoriality) should be able to take into account the processes of personalization and slowing-down/acceleration (of space-time disorientation) of traditional knowledge while those processes progressively shape themselves into the practices of the web. In these everyday interactions, an irreparable fracture of the values embodied in education and dissemination takes place: from the collapse of the contents transmitted from the top down comes the strength of contents that will gradually upset the original intentions. Literacy is thus reversed into de-literacy (as a transition towards other forms of expression) and dissemination is reversed into de-dissemination (as a transition towards other forms of local vernacular idioms, towards other emerging dialects). These inversions of communication, these critical innovations, must therefore be read also outside of the usual social prohibitions which are based on the purely statistical revelation of the phenomena of de-schooling and neo-literacy, and which are analysed according to paradigms still based on the alphabet and on the school.

5. The regimes of double truth are rooted in the abandonment of the regimes of the sacred, of a truth that lies in the inexplicable, that withholds itself from human knowledge, and in the emergence of a religious spirit that cleaves between the earthly and the heavenly nature of the individual. Christianity represents the highest degree of this dual nature, which is already sanctioned in the Old Testament with the invention of an extraordinary tale: having tasted the forbidden fruit of knowledge, and - as much iconography has suggested - of pleasure, the human being is expelled from the Garden of Eden, a world in which, in the image of God, there exists no need to be thrown into the pains of childbirth and work, of death and desire. Already, in the first exodus, the dialectic is marked, between the city of man and the city of god, between heaven and earth: the principle of hope that arises with the sacrifice of a God who became a man so that mankind, forever and ever since that rite, will always recognize itself as both divine truth and mundane truth. 
reproduction. On the other hand, it is expressed in an instrumental assessment of the market, of its economical and political dynamics, which are assumed to be vital both for technological development and for the civil society.

In the first case, what prevails is the institutional need to step out from the unstoppable encroachment of technologies that the educational models of the modern subject depict as alien and therefore inhuman. In the second case, the state of necessity of the individual, the will to power of the human being, prevails. Therefore, in the latter case, there is a prevalence of the original innate violence that the societal models of history have channeled and structured - both rationally and irrationally ${ }^{6}$ - along the progressive line of a present time of compromise and of a salvation to come. The dialectics of civilization have marched along the axis of this double-crossing between positive and negative ideologies.

\section{THE NONSENSE OF THE SACRED}

The path traced by Jürgen Habermas in the early 1960s is essentially progressive: ${ }^{7}$ it goes from the pseudo-collective mental representations (virtually representative, parliamentary) designed by the elite readers of the eighteenth-century press, to the conjuringup of public opinion, to its actual birth in the form of civil consciousness. An ideally universal set of rights and interests. On the contrary, however, the path in which the western world was finally confined consisted, and more and more consists, of a return of public opinion into the order of the institutional media within the tendentially chaotic

6. From our mediological point of view, the trial undertaken by the royal committee to scrutinize the true scientific value of Mesmer's medical practices - a trial that ended with a verdict sanctioning the method and its results as unscientific, but that still resulted in a resounding recognition of the powers of imagination - is the best example of the fact that, during the era of the Enlightenment, the lines of rationalism and those of non-rationalism became intertwined into a single form of development, into the same dramaturgical script.

7. See Habermas's Strukturwandel der Öffentlichkeit. Untersuchungen zu einer Kategorie der bürgerlichen Gesellschaft (1962), an essay that somehow comes just a few years after the publication of the Dialectic of Enlightenment (Adorno and Horkheimer 1947), the same years that yielded the first essays on the media by McLuhan. This contribution, however, disregarded a passage, a brief but extraordinarily important piece from that fundamental contribution to the critique of cultural industry (so close to and yet so far from Walter Benjamin's pages), in which, after having supported the thesis of a radical and irreconcilable opposition between mass culture and high bourgeois culture (a thesis that even to this day has been the driving one among the most politically committed intellectual class), Adorno and Horkheimer mark a far more significant, though less fortunate difference. Their discourse in fact leads them to pinpoint the incompatibility between the contents of civilization - in which they include the culture of the media as well as the highest intellectual and aesthetic traditions - and the expressive experience of the historical avant-garde: the only ones to recognize the substantial non-sense of modern society. Since then, the debate about technology has continuously focused - comprising several different critical positions, at times basically positive, at times leaning towards the negative - on the relationship between technology and the empowerment of the individual and of civil society, away from an unjust, servile life. And this debate has very often distinguished two different forms of progress, depending on which technological choices are made, basing such distinction on the separation between good and bad technologies, rather than, as would be only slightly more correct, between a good and a bad use of technology in itself. See also: Adorno and Horkheimer (2002); Benjamin (1983; 1999); Benkler (2006); Carr (2010); Habermas (1991); Kelly (2010); Lanier (2010); McLuhan (1994); Rodotà (2004); Shirky (2008); Weinberger (2007). 
sphere of the mental representations induced by the market media, and of the centrifugal multiplicity of its objects of consumerism. The civilizing thrust of the first path (from the reader to the voter) and the barbaric thrust of the second path (from the person to the consumer) collide, and at the same time contaminate each other at the point of intersection between two different forms of awareness: conscious and unconscious, with both of them permeated by strong emotional perturbations.

There has therefore been a constructive phase, in which the dominant medium on the formation of social identities was reading, but from this, gradually and progressively, we have reached a destructive stage, which today is at its apogee, in which the forms of representation are precisely de-structuring the relationship between public as citizenship and the public as territory of individual consumerism, as tribal regimes of desire. We are faced with a double movement between opposing values (what has value and therefore is important, has to be; hence the things through which to see and hear the world). Values expressed on a global scale through the Western model of development. These are two opposing tensions, often merged into each other, between human and inhuman, need and desire, order and disorder: a force field, however, in which the particular virulence of profoundly anti-modern processes and practices are emerging (often adopted in a purely reactionary, 'realistic,' attitude and therefore still bound to the contradictions of modernity). The arena of this intersection between values of opposing signs, but belonging to the same, unique, history of modernization processes, is now represented by the territory of digital networks: that is to say, by the fluidity of interpersonal relationships in which the human, animal, destinies are now more and more devoted to hyper-consumerism, ${ }^{8}$ and the fates of the economic and political apparatus of power - which in turn are devoted instead to the hyper-control of social life, to its enslavement - may both be advantaged by virtue of a media prowess that is technologically much more ductile than previously. ${ }^{9}$ To continue with such simplifications: the relationship between writing and image, public opinion and entertainment, ${ }^{10}$ has kept changing with the unfolding of modern times, managing

8. In light of this passage, the divergence of technological development between public interest and private interest can be explained. And one of the most eloquent signs of this divergence is the political crisis that expressed itself in the sharp rise of populist tendencies - previously considered typical of pre-modern, obsolete power systems - even within historically established democratic systems, and firmly based on the principles of parliamentary representation. See: Albertazzi and McDonnell (2008); Asor Rosa (1966); Capelli (2008); Eco (2006); Flores d'Arcais (1996); Taggart (2000); Taguieff (2002); Tarchi (2003).

9. Compared to the proven functionality of analogic media (photography, cinema, radio, and television), that is to say, compared to the high degree of compatibility with which the quality of the medium has corresponded to the quality of the political-economic system that generated it, the languages of the web seem to be freer to perform widely divergent tasks. But this may be due merely to the fact that these new languages are still in the negotiation phase that has also characterized the stabilization of the functions assigned to the earlier media. The vast literature on networks is debating this point exactly: whether they are a vehicle of newness or, instead, an expression of its negation. The debate should be addressed mainly considering its contradictions. For example, it should be focused on the fact that the ideological 'continental divider' is in truth a category wholly typical of the modern tradition, that is - the new, which incorporates a set of values that, while opposing each other, have in common the same vision: the progress of the individual - intended as emancipation and liberation or hope of liberation from social constraints that limit one's freedom of thought.

10. The highest point of the critique of the relations of symbolic production among the systems of western life is to be found in the analyses produced by the situationists, who radicalized in a militant direction the paths of Frankfurt thought (see Debord 1995). In fact, they acted in an 
to retain for nearly two centuries a certain balance between rational and instrumental civil functions; the functions strictly tied to the media conformed to the regulatory and educational spirit of writing; and the emotional functions (irrational, socially evasive, and transgressive) of the market media - that is to say, the media founded on the arcane nature of goods, the symbolic density of consumerism, of pre-modern forms of religion and worship. The cultural industry, from the Great Universal Exhibitions to the classic Hollywood movies, have transformed writing from a power device based on reading to a control device for the production of images scripted according to its canons, and its great or trivial narratives. In the terminal phase of television and finally in the floating life of the web, we have gone from the religiosity of the collective mental representations, from its exceptional ability to mythologize everyday life ${ }^{11}$ to an infinitely more complex relationship between writing and images: the proliferation of images that have become the hegemonic device in terms of consumerism has enslaved writing by marginalizing its historical functions while strengthening its market functions: the narratives of television fiction series of the latest generation are now springing from images that script themselves, that write the screenplays about themselves. The original root of the relationship between writing and reading, which for so long had a hegemonic role in society - with forms of power and intellectual figures mandated to implement them on the technical and aesthetic levels - has collapsed. The regenerated myth of mass culture declines and causes the decline - while still exalting it as much as possible - of its own power in a realm that is increasingly less a symbolic order compatible with the social order, and that is becoming less and less a direct instrument of shared political reality. The religious spirit - even the most mundane, disenchanted, secularized - shatters like a mirror. The viewer self-consumes, being absorbed and dominated by the sense of the sacred that is produced in the ever more radical imbalance between bodies and flesh: ${ }^{12}$ between the ideology of needs, based on which the public and private institutions negotiate their social contracts, and the inexhaustible drive of desire, which, as such, in its sidereal dimension, has no way to find, or find again, nor to invent any satisfaction, be it earthly or divine. The extremely long duration of the processes of secularization is being completed on the 'other side' of the modernization processes that have marked its most extreme, radical phase. These processes have had their genesis in the linear development that tied together the classical tradition and the Judeo-Christian one, which in turn led up to Humanism, a form of religiosity able to achieve the same social effectiveness, the same political solidity, despite being split between the sky and earth, between the city of God and the city of Man. Now, however, all kinds of religiosity, even outside the Christian world, give room - surrender territories - to the nonsense of the sacred (paradoxically, here the cusps of the blindest fundamentalism are reached,

intentionally abstract way, aiming to achieve the same purity of the abstractions of the capital; paradoxically, this was therefore the most compatible method of intellectual production with the public (propaganda) and private (advertising) policies intended to shape the collective mental representations. Such policies aimed at fully subjecting the symbolic space by occupying the whole sphere of its expressive relations: the entertainment (of society) and the society (of entertainment). A process that in its rigor had to renounce the aesthetic gratifications of the historical avant-garde, related to the recognition, albeit by negation, irony, and dissolution, of the forms of social interactions staged by showbusiness and even by the institutions themselves (for example: the museum).

11. See: De Certeau (1984); Durand (1960); Maffesoli (1996); Morin (1962; 2005a; 2005b).

12. For this seminal distinction between body as social entity and flesh as its psychosomatic and emotional extension, see: Esposito (2008; 2011); McLuhan (1962; 1964). 
the forms of the deepest disenchantment, and the most hybrid forms, both monotheistic and polytheistic, of religions invented in a scenario similar to science fiction). Without taking into account this momentous transition, it is impossible to rethink any content and vehicle of cultural and professional education.

\section{THE REMAINS OF THE CIVILIZATION}

Within the above described post-historical transitions, we have to frame the issue of the ruling classes in the present Italian (and also global) situation, in which they have fallen to the lowest levels of disrepute. They, themselves - albeit in an often exceedingly rhetorical, and too rarely self-aware mode - recognize their own loss of reputation, and yet the analytical tools they use seem to exacerbate this problem, rather than solve it. Italy, anyway, is a privileged field of analysis because of its extremely severe condition. Its cultural institutions exist in a social context that, while occupying the high end of modern development, is also emblematic of a territoriality swept by deep anti-modern currents. These are so extreme as to uncover truly post-modern scenarios. Such scenarios, at least for the time being, are indeed hidden within, or removed from, more robust social systems that still manage to flow steadily within the riverbanks of their own history. The need for the ruling classes to regain a good reputation forcibly raises a question: can these classes rebuild a reputation through their traditional structures and their educational models? Are these structures and models - so unwilling to divest their ideologies of identity, rooted as they are in modern society and in its ancient traditions - able to recover some efficacy without resorting to anti-religious contents? Outside of institutions such as schools and universities, as well as outside of the corporations, can the collective media-induced mental representations provide an alternative way, in terms of representation of the contemporary world and thus of the creation of the critical content necessary to educate and train the ruling classes? Here we can answer only by transforming the complexity of these questions into assertions (and, thus, subjects on which to open a discussion): the current ruling classes' thought is constrained by an unchangeable anthropological substrate (it would be like asking a freshwater fish to live in the sea); the introduction of anti-religious thought in an institutional context requires a very long period of time, and is totally impractical unless the processes of research and training are put into place in an unprecedented way (for instance, resorting to genius, or avant-garde, or viral strategies); the mental representations of the consumerist media are basically schizoid. This unveils a radically post-human world, less and less religious, and more and more primal and savage, which nonetheless holds onto the present social habits and, even if with lower efficacy than in the past, keeps them alive. This everyday affectivity, which anyway is part of the social and institutional fabric that supports it, is called directly and indirectly to act as a placebo able to induce the delirious spaces of desire to live together with those forcibly required by common sense, by need, by necessity. In other words, it provides no direct means to address the social life, other than to bear it; and, perhaps, it stimulates an inclination to simulate its final and complete catastrophe, to become addicted to its end. It is a desperate exodus (with pleasure replacing hope) that transforms the forms of superficial entertainment into a slow inner mutation. And as such, if endorsed by the instrumental thinking, this mutation becomes, if anything, its more sophisticated prosthesis. Otherwise it constitutes an experience that lives elsewhere. It becomes a part of the remnant, that 'in the beginning' civilization has only considered as a theatre stage for a god, be it human or divine. 


\section{THE RULING CLASSES AND THE FAILURE OF HUMANISM}

To touch here upon the theme of reputation, in such a dramatic situation, in Italy and throughout the world, forces one to look, at the same time, to the present and to the future. It forces everyone who feels responsible for their human and social environment to continue their profession, their role. They may do that in the immediate present, but they are forced to think of themselves with equal urgency in a radically different way from the one in which everyone is now, and always will be, forced to think as a social identity. In short: the state of necessity here has to be opened to the cohabitation between two forms of responsibility, while these are so irreconcilable as not to allow any mediation between them. One, imprisoned in a modern religiosity, and the other locked instead in its tragic impossibility of accomplishment, in its own non-sense: into the sacredness of the pain of existing, that the religious spirit at once denies and produces, and translates into hope. What I am trying to summarize here in a few notes, envisions such long periods of time as to clash with the practical emergencies imposed upon us by the world we live in. True. However, equally true, but far more aberrant (and doomed to failure), is the illusion of those who believe they can restart the use of skills adequate to our present time only by slight day-to-day revisions of the educational quality of the existing institutions. Certainly, it will not be possible to recover in a few years - maybe not even in a few decades - all that has been dissipated, and, more importantly, removed since the attempt at rebuilding the post-atomic twentieth century. Then, it is necessary to escape the reformist syndrome which has destroyed the university in its attempt to conform it to the changes in the same part of the world for which it was born; and in so doing has deprived it of the opportunity to produce, and therefore anticipate, paradigm shifts elsewhere, outside of the history and the society of modern times. Elsewhere: in the self-questioning of the person, and not through listening to the otherness that the devices of individualism have opposed to it deploying every possible dialectic skill (the contemporary 'decadent' thought is filled with rhetoric about the other, and such rhetoric is but an alibi for modern subjects' stubborn will to survive).

The space of the person who sees himself, manages to find himself, beyond anthropocentrism disintegrates every historical and social tie: for this reason, this endeavor has to be attempted only after having first of all revealed the failure of Humanism, of all the contents that have been the pillars of Western knowledge, which still form the pillars of the very idea of scientific community. ${ }^{13}$ To proceed along this path, unless - made wise by the evidence - one has the courage to make a clean sweep of all knowledge accumulated to date, it is necessary to face the huge work of the re-interpretation of Western thought. It is also necessary to reassess in a political sense (the sense of inhabiting) those solitary and dazzling pages that between the nineteenth and twentieth centuries had reached - albeit almost always under some sort of underlying, desperate hyper-humanism ${ }^{14}$ - a high

13. To begin with the overcoming of every ethical horizon of collective content - related to solidarity, universality - it is not only the idea of the original community (derived from that totalitarian horizon that is again and again retrieved and re-utilized at every growth-crisis of society) to be revealed as impossible, but it is also the idea of scientific community, because, when bringing the thought of ethical dimension into the person, not only the uniformity of action and intent of a group or class, but also its uniformity of method as well as the whole of its shared content, does not hold, must not hold. See: Agamben (2005); Bauman (2001); Esposito (2004); Hardt and Negri (2009); Nancy (1996); Sennett (2012).

14. See, for example, Max Stirner, famous above all for The Ego and Its Own (1995), who also wrote Das unwahre Prinzip unserer Erziehung oder der Humanismus und Realismus [The False Principles of Our Education or Humanism and Realism] (1911). 
degree of awareness of the limitations of Humanism and of the lies implicit in every religion. So it is also necessary to deal with the ambiguous twentieth-century grandeur of psychoanalysis and its practices: an innovation of thought that has taken care of the non-sense of the individual but, ultimately, in its own disclosure, doing this simply in order to adapt the individual to the non-sense of society. ${ }^{15}$ And, finally, to demystify the post-industrial turning point of some Marxist traditions that, finding the subject of the conflict in the naked life of the people instead of in the proletariat, substitute universal love for class-hate. ${ }^{16}$

15. This ambiguity explains the more intellectual and even visionary 'American' side of the Frankfurt School, in which Freud was used to interpret the disease of capitalist society and the self-liberating impulses of those who objected to it, both in individualistic and generational terms, while remaining within the revisionist logic of the same values of civilization (see Horkheimer 1947). It also explains the interplay between the artistic avant-garde and psychoanalysis, since the latter has provided a veritable repertoire for and about the collective imagination, emphasizing the difference between the emergence of the 'unconscious' and the realism of the traditional models of social control on the forms of representation; see for instance the surrealism of Breton, etc. Finally - although the relationships between psychoanalysis and upper-class bourgeois culture have now been supplanted by those between the middle classes and the therapeutic care-system of the ordinary discomfort of the consumer society - we observe the unveiling of the ambiguity between the psychoanalytic analysis of a person and an ideological clinical discipline, which remains substantially religious even when it is secular and civil. See, for instance, Massimo Recalcati $(2007 ; 2010)$.

16. On this point I elaborate on some of my participation in the annual workshops of the CEAQ, previously published in Les Cahiers Européens de l'Imaginaire. The protagonist of the re-channeling of class hatred towards love as an original critical dimension is Toni Negri (see the chapter 'Governing the revolution,' in Negri and Hardt 2009). This passage recalls Foucault's lectures at the University of California at Berkeley in 1983, a year before his death, which are collected in Fearless Speech (2001). For parresia we mean the obligation to tell the truth at one's own risk, the typical formula of right-and-duty founded on human freedom (Socrates' act). Although formulated by the political canon of Athenian democracy, and taken up by Christianity and finally by the democratic 'national interest,' this concept has been gradually adapted - religiously, socially - to the idea of katechon (St Paul) as a waiting time for the ultimate truth: a politically opportunistic time, progressist necessity, revival of a 'better' that is perpetually to come. The current dismay and daze of policies, and of social and cultural institutions when faced with the might of a crisis that no public agency is able to control, now makes it possible to presume to be able to revoke the utilitarian wisdom of the katechon, thus reverting to more radical, less wait-and-see and compromisory virtues. But it also brings us to interpret - in a purely moralistic and ideological way - parresia as the urgency to claim the truth of values that will contrast new (after the rapture of the collective myths) with prevailing forms of power. Their cruelty. Their mercilessness. In essence, this return of intellectual militants to a sort of priesthood - as truth-seekers, who in this search are satisfied and want to satisfy the others in the name of a new faith, of a more authentic and promising liberation of the human being - seems to resort to parresia as the right to speak one's own truth even when, especially when, such truth states something contrary to the established power. But these were exactly the freedoms granted by modernity, the purpose of democracies which, however, have not reached a good end. And therefore it seems to me that the 'to say what has to be said' should instead bring forward the socially unheard of, the thing that causes the 'death' of every other presumption of life. Of every other faith, be it secular or religious. The etymological meaning of episteme - that is, truth, in Greek - tells us that what is worthy of parresia is 'what stays up, holds, by itself,' with no need to be supported by any authority except itself. And thus, without resorting to doxa - that is, propaganda, religion, power. If this is the meaning of the word parresia as a finally resolutory word, I do not see the possibility of any other truth that is not within the indubitable, absolutely unchangeable nature of human suffering: its desire for power and, with it, inseparable from it, the pain, the suffering it produces. Parresia is 
40 Leadership and the Humanities, Vol. 1 No. 1

an irrevocable 'knowledge of pain,' to keep in mind whenever the language of the human being intends to build the meaning of its own freedom upon the difference between the human and the non-human world. In other words, we must ask ourselves whether it is not necessary to inaugurate a divorce between the acts of thinking and doing of society. To revoke humanism as basic science for the education of the person and the ruling classes. To separate as much as possible the pain of the flesh from the roles assigned to their bodies. To force thought towards this hypothesis of personal, 'inner work' means also to meditate on some issues that modern society has left unresolved. First of all, what capitalism is: to verify whether the idea that the evil empire resides in the mode of production of machines and worldly goods or, rather, whether it is in human nature, or more precisely in the craving for power that makes it part of the non-human nature, before and after the era of capitalism (on this going past the economic capital towards deeper forms of sovereignty, see, beyond the imaginative thinking proposed by Bataille 2007). 


\section{REFERENCES}

Abruzzese, A. (1996), Analfabeti di Tutto il Mondo Uniamoci, Genova: Costa \& Nolan. Abruzzese, A. (2011), Il Crepuscolo dei Barbari, Milano: Bevivino.

Adorno, T.W. and M. Horkheimer (1947), Dialectic of Enlightenment: Philosophical Fragments, Stanford: Stanford University Press.

Agamben, G. (2005), State of Exception, Chicago: Chicago University Press.

Albertazzi, D. and D. McDonnell (2008), Twenty-First Century Populism: The Spectre of Western European Democracy, London and New York: Palgrave Macmillan.

Asor Rosa, A. (1966), Scrittori e Popolo, Torino: Einaudi.

Bataille, Jongen M. (ed.) (2007), Divine Capitalism. A Conversation about Money, Consumption, Art and Destruction with Boris Groys, Jochen Hörisch, Thomas Macho, Peter Sloterdijk and Peter Weibel, München: Wilhelm Fink Verlag.

Bauman, Z. (2001), Community. Seeking Safety in an Insecure World, Cambridge: Polity.

Benjamin, W. (1983), Charles Baudelaire: A Lyric Poet in the Era of High Capitalism, London: Verso.

Benjamin, W. (1999), The Arcades Project, Cambridge, MA: Harvard University Press.

Benkler, Y. (2006), The Wealth of Networks. How Social Production Transforms Markets and Freedom, New Haven, CT and London, UK: Yale University Press.

Bloch, E. (1959), Das Prinzip Hoffnung, Frankfurt am Main: Shurkamp Verlag.

Bolter, J.D. and R. Grusin (1999), Remediation: Understanding New Media, Cambridge: MIT Press.

Capelli, F. (2008), Sinistra Light. Populismo Mediatico e Silenzio Delle Idee, Milano: Guerini e Associati.

Carr, N. (2010), The Shallows: What the Internet is Doing to Our Brains, New York: W.W. Norton.

Debord, G. (1995), The Society of the Spectacle, New York: Zone Books.

De Certeau, M. (1984), The Practice of Everyday Life, Berkeley: University of California Press.

De Kerckhove, D. (2008), Dall'Alfabeto a Internet. L'Homme 'Littéré': Alfabetizzazione, Cultura, Tecnologia, Milano: Mimesis.

Durand, G. (1960), Les Structures Anthropologiques de l'Imaginaire, Paris: Dunod.

Eco, U. (2006), A Passo di Gambero. Guerre Calde e Populismo Mediatico, Milano: Bompiani Overlook.

Eisenstein, E. (1979), The Printing Press as an Agent of Change: Communications and Cultural Transformations in Early Modern Europe (2 vols), Cambridge, UK: Cambridge University Press.

Esposito, R. (2004), Communitas: the Origin and Destiny of Community, Stanford: Stanford University Press.

Esposito, R. (2008), Bìos: Biopolitics and Philosophy, Minneapolis: Minnesota University Press.

Esposito, R. (2011), Immunitas: the Protection and Negation of Life, London: Polity Press.

Esposito, R. (2012), The Third Person, London: Polity Press.

Flores d'Arcais, P. (1996), Il Populismo Italiano da Craxi a Berlusconi. Dieci Anni di Regime Nelle Analisi di MicroMega, Roma: Donzelli.

Foucault, Michel (2001), Fearless Speech, Los Angeles: Semiotext(e) - Foreign Agents.

Frasca, G. (2005), La Lettera Che Muore. La 'Letteratura' Nel Reticolo Mediale, Roma: Meltemi.

Habermas, Jürgen (1962), Strukturwandel der Öffentlichkeit. Untersuchungen zu einer Kategorie der bürgerlichen Gesellschaft, Berlin: Auflage, Neuwied.

Habermas, J. (1991), The Structural Transformation of the Public Sphere, Cambridge, MA: MIT Press.

Hardt, M. and T. Negri (2009), Commonwealth, Cambridge, MA: Belknap Press of Harvard University Press.

Harris, R. (1986), The Origin of Writing, London: Duckworth.

Havelock, E.A. (1963), Preface to Plato, Cambridge, MA: Harvard University Press.

Havelock, E.A. (1986), The Muse Learns to Write: Reflections on Orality and Literacy from Antiquity to the Present, New Haven, CT: Yale University Press. 
Horkheimer, M. and Th.W. Adorno (1947), Dialektik der Aufklärung. Philosophische Fragmente, Amsterdam: Querido Verlag.

Illich, I. (1993), In the Vineyard of the Text: A Commentary to Hugh's Didascalicon, Chicago: University of Chicago Press.

Innis, H. (1951), The Bias of Communication, Toronto: University of Toronto Press.

Innis, H. (1950), Empire and Communications, Oxford: Oxford University Press.

Kelly, K. (2010), What Technology Wants, New York: Viking Press.

Kristeva, J. (2011), The Severed Head: Capital Visions, New York: Columbia University Press.

Landow, G.P. (1992), Hypertext: The Convergence of Contemporary Critical Theory and Technology, Baltimore, MD: Johns Hopkins University Press.

Lanier, J. (2010), You are not a Gadget, New York: Vintage Books.

Maffesoli, M. (1996), The Time of the Tribes, London: Sage.

McLuhan, M. (1962), The Gutenberg Galaxy: The Making of Typographic Man, Toronto: University of Toronto Press.

McLuhan, M. (1964), Understanding Media. The Extensions of Man, New York: McGraw-Hill.

McLuhan, M. (1994), Understanding Media, Cambridge, MA: MIT Press.

Moretti, F. (1996), Modern Epic: The World System from Goethe to Garcia Marquez, New York: Verso.

Morin, E. (1962), L’Esprit du Temps, Paris: Éditions Grasset Fasquelle.

Morin, E. (2005a), The Stars, Minneapolis: University of Minnesota Press.

Morin, E. (2005b), The Cinema, or the Imaginary Man, Minneapolis: University of Minnesota Press.

Nancy, J.L. (1996), Etre Singulier Pluriel, Paris: Galilée.

Negri, T. and M. Hardt (2009), Commonwealth, Cambridge, MA: Harvard University Press.

Ong, W.J. (1982), Orality and Literacy: The Technologizing of the Word, New York: Methuen.

Recalcati, Massimo (2010), L'Uomo Senza Inconscio. Figure Della Nuova Clinica Psicoanalitica, Milano: Raffaello Cortina.

Recalcati, Massimo (2007), Elogio Dell'Inconscio. Dodici Argomenti in Difesa Della Psicoanalisi, Milano: Bruno Mondadori.

Rodotà, S. (2004), Tecnopolitica. La Democrazia e le Nuove Tecnologie Della Comunicazione, Laterza: Roma-Bari.

Schopenhauer, A. (1851 [1974]), Parerga und Paralipomena, English translation by E.F.J. Payne, Oxford: Clarendon Press.

Sennett, R. (2012), Together. The Rituals, Pleasures and Politics of Cooperation, New Haven, CT: Yale University Press.

Shirky, C. (2008), Here Comes Everybody. The Power of Organizing Without Organizations, New York: Penguin.

Stirner, Max (1995), The Ego and its Own, Cambridge and New York: Cambridge University Press.

Stirner, Max (1911), Das unwahre Prinzip unserer Erziehung oder der Humanismus und Realismus [The False Principles of Our Education or Humanism and Realism], John Henry Mackay (ed.), Dornach: Verlag am Goetheanum.

Taggart, P. (2000), Populism, USA and UK: Open University Press.

Taguieff, P.A. (2002), L'Illusion Populiste: De L’Archaïque au Médiatique, Paris: Berg International.

Tarchi, M. (2003), L'Italia Populista. Dal Qualunquismo ai Girotondi, Bologna: Il Mulino.

Weinberger, D. (2007), Everything is Miscellaneous: The Power of the New Digital Disorder, New York: Henry Holt. 